DOI: $10.2478 / \mathrm{v} 10025-009-0011-\mathrm{z}$

JOURNAL OF WATER

AND LAND DEVELOPMENT

J. Water Land Dev. No. 12, 2008: 145-153

\title{
Bankfull discharge determination using the new Invertebrate Bankfull Assessment Method
}

\author{
Artur RADECKI-PAWLIK ${ }^{1)}$, Tomasz SKALSKI ${ }^{2}$ \\ 1) Agricultural University of Cracow, al. Mickiewicza 24-28, 30-059 Cracow, Poland, e-mail: \\ rmradeck@cyf-kr.edu.pl \\ ${ }^{2)}$ Institute of Zoology, Jagiellonian University, Ingardena 6, 30-060 Cracow, Poland
}

\begin{abstract}
Along the paper the new method called Invertebrate Bankfull Assessment method (IBA method) of determination of bankfull discharge is presented. The investigation of bankfull discharge using IBA were performed within one Polish Carpathian stream in the mountain region: the Ochotnica Stream. As an index of bankfull the existence of certain species of invertebrates was used which are present and resistant to specific water discharge conditions. The borders within a cross section of the mountain stream with a gravel bed were defined where characteristic invertebrates are present which are recognized as bankfull borders. Finally three invertebrates benches (IB-ms) were recognized which are characterized by very specific invertebrate species. Bankfull discharge was calculated up to this IB-ms and corelated using Canonical Correspondence Analysis with other values of bankfull calculated for a cross section using different bankfull.
\end{abstract}

Key words: bankfull discharge, mountain stream, ground beetles, biomass, Polish Carpathian Mountains

\section{INTRODUCTION}

It has long been known that between the flow in a channel and its geometry the empirical relationship exists (WERRITTY, 1997). Thus, river channel formation is a result of the constantly changing discharge, and one of them is bankfull. A wide range of terms and definitions of bankfull is evident in scientific literature. Some of the most important were provided by WILIAMS (1978) and RADECKI-PAWLIK (2002). The authors approached not only simple description of bankfull but also analysed chosen methods of its calculation. Among many definitions of bankfull discharge and ways of its calculations those which are the better known are given by WILLIAMS (1978), WOODYER (1968), NIXON (1959), SCHUMM (1960), BRAY (1972), PICKUP and WARNER (1976), RILEY (1972) and WOLMAN (1955). This paper examines the Invertebrate Bankfull Assessment Method (IBA- 
-method) for mountain alluvial stream with the gravel bed proposed by RADECKI-PAWLIK and SKALSKI $(2007,2008)$. In the era of the close cooperation of many interdisciplinary scientists such geo-hydro-biological sort of approach towards finding bankfull value seems to be an alternative way. For the purpose of this study from the Woodyer study the authors adopted the name "bench" to show the levels to which the water has the influence on changes of terrestrial communities.

\section{METHODS}

Bankfull discharge was determined within the Ochotnica Stream research reach. The reach is situated in Polish Carpathians (the Gorce Mountains). The stream has a large catchment area $\left(55 \mathrm{~km}^{2}\right)$ as for its length $(12 \mathrm{~km})$. Some basic physical characteristics of the Ochotnica stream are: precipitation $900 \mathrm{~mm}, Q_{50 \%}=$ $11.3 \mathrm{~m}^{3} \cdot \mathrm{s}^{-1}, Q_{25 \%}=21.2 \mathrm{~m}^{3} \cdot \mathrm{s}^{-1}, Q_{20 \%}=25.4 \mathrm{~m}^{3} \cdot \mathrm{s}^{-1}, Q_{10 \%}=38.4 \mathrm{~m}^{3} \cdot \mathrm{s}^{-1}, D_{50}=20.2$ $\mathrm{mm}$. There are two main ways of how different authors define bankfull. The first group of definitions describes bankfull in terms of the geometry of a cross-section, the second group of definitions describe it as a bankfull discharge in terms of volume of water. Detailed description of how to calculate bankfull according to different definitions was provided by RADECKI-PAWLIK (2002) with schedule-graphs, formulae and field test results. Generally speaking bankfull value could be found out in two ways, or if one wishes bankfull value calculation methods could be divided into two groups. The typical example of the first group of methods is that proposed by WOODYER (1968). The author identifies three river benches - low, middle and high - in terms of the annual maximum series, and uses vegetation cover to verify results. His method may be particularly successful in mountain creeks where plants are abundant. Also to this group one can classify WOLMAN (1955) and RILEY (1972) methods. The second group of methods defines bankfull as a bankfull discharge in terms of volume of water. Here the Gauckler-Manning flow equation (PICKUP and WARNER 1976) is one of several equations, which can be used directly at a station to determine bankfull discharge. In the present study typical alluvial and braided cross-sections situated approximately in the middle of the Ochotnica Stream were chosen. The selected cross-section exhibited a range of characteristics in terms of bank river benches, vegetation, and riverbed configuration. A detailed survey was undertaken using geodesy instruments and field water gauge. Later, bankfull discharge values were calculated according to the methods of Wolman, Woodyer, Schumm and Brown, Woloszyn and Williams. Having all that done, ground beetles were used to find bankfull as an indicator - as it was done similary in other studies (RAINIO and NIEMELA, 2003). Ground beetles are very abundant in many riparian habitats (ANDERSEN, 1969) in temperate regions. The structure of beetle communities reflects responses to frequency of disturbance. In near-water habitats seasonal flood plays a key role. Different fluctuations of wa- 
ter level at different levels above the benches create more or less favourable conditions for accumulation of food necessary for adult egg laying. Among the adult forms the female need enough time for collection of energetic resources for egg hatching (THIELE, 1977). Here we assume that water flooding occurring more or less frequently causes sustain alteration in abundance of taxa, often resulting in the elimination of some taxa in the favour of less competitive but more adopted species. First of all such disturbance eliminates food supplies in the changing environment. In consequence predators should be smaller and with big dispersal power. In general, disturbances often have disproportionately strong negative effects on larger species than on smaller ones (WOODWARD et al., 2005). In that case more frequent disturbances provides less food for accumulation, then in consequence only smaller animals can survive and have reproduction success. In a changing environment there is a specific trade-off between preferences for increase body mass and adaptation to changing condition. Such a relation could be used as a method of assessment of bankfull discharge using the so-called biotic index. Here is tested the application of ground beetles community structure as a method of assessment of particular level or bench associated with specific $t$-years flood level and later linked to a bankfull level. Firstly the level of adequate $t$-year flood is defined and then comparing it with the levels which were then associated with the presence of specified invertebrates. In the chosen research river cross section twelve localities were chosen that differed in the distance to the base level which in this specific case was a level cut through the point of the highest tawleg altitude. Also in the examined cross section there are three braids which are very characteristic for the morphology of the Ochotnica stream. At each localities within the examined cross section ten pitfall traps (plastic cups with $10 \%$ of ethylene glycol) were installed. Samples were taken monthly throughout the whole vegetation season. At each locality four samples were taken. Ground beetles were then sorted and preserved in $70 \%$ alcohol for further identification. For each locality ground beetles community structure parameters such as total abundance, richness, species diversity and its evenness, body length and biomass were calculated. In most communities the distribution of abundances in size classes is unimodal. RIBEIRA et al. (2001) showed that significantly more small species were presented in disturbed habitats. So it is hypothesized that the distribution of particular size group in riverine community will change with frequency of floods. Thus in more disturbed habitats the proportion of the smallest toward medium sized beetles will be good predictor and can be applied as an indicator of habitat changes. In this manner it is proposed that the formula of bankfull assessment can be tested in particular example of the Ochotnica stream research cross section in Polish Carpathians:

IBA index $=$ abundance of 1-6 mm specimens/abundance of 18-24 mm specimens 
Such a simple index allows anybody to collect species within any cross section, measure them and classify them into size groups. Next heaving the value of the index and the level/altitude of a particular class/community occurrence and also at the same time having the level of the calculated $t$-year flood for the particular cross section, a bankfull level could be easy to asses from the rating curve. Application of such formulae was tested by multivariate statistical methods. Principal Component analysis, an indirect multivariate method was chosen to examine the distances between assemblages of beetles and their similarities. Because the distribution of particular species on three benches is not continuous and is not revealed as a Gausian unimodal type, the linear model was applied in such analysis. To examine the relationship between ground beetle assemblages and environmental variables direct gradient analysis, Canonical Correspondence and Redundancy Analyses was applied (TER BRAAK, 1986). To test the species responses, CCA which included unimodal distribution of each species was applied. In case of variation of community parameters RDA (a linear method) seemed to be more suitable. Each multivariate method was chosen according to maximum level of variation described in the analysis.

\section{RESULTS AND DISCUSSION}

The distribution of abundances of the communities in different body size classes was assessed and it was found that in the research section - all communities from the first bench have left skewed distribution toward smaller species. Assemblages, however from the second and third benches, have the most species belonging to medium sized species. In every assemblage from the first bench, the proportion of very small specimens to medium sized is always bigger than 1 , meanwhile on the second terrace it is always lower than 1. In the third one there is almost no small body sized specimens at all. The most abundant species from the community (dominant one) are also the another good method of assessment of each bench. Knowing the density of most abundant species and measuring its length it is possible to calculate the total biomass which later can be used also as a good predictor of bank level. As it is shown in Figure 1, it is possible to empirically predict the value of bench according to equation $y=147.15 e^{1.5239 x}(t=4.72, p=0.0008)$, where $x$ is known biomass of dominant species in given bench. After such assessment of the data the IBM index was calculated or all the identified benches. Later bankfull was calculated using all the abiotic methods referred too above. All plant species were identified along our research cross section, and in this manner three river benches were delimited according to Woodyer's postulates. Finally these benches were associated with the levels at which were placed the invertebrate traps. In this way were calculated the bankfull values also for those two biotic methods. The results of calculations of bankfull values using all the methods 


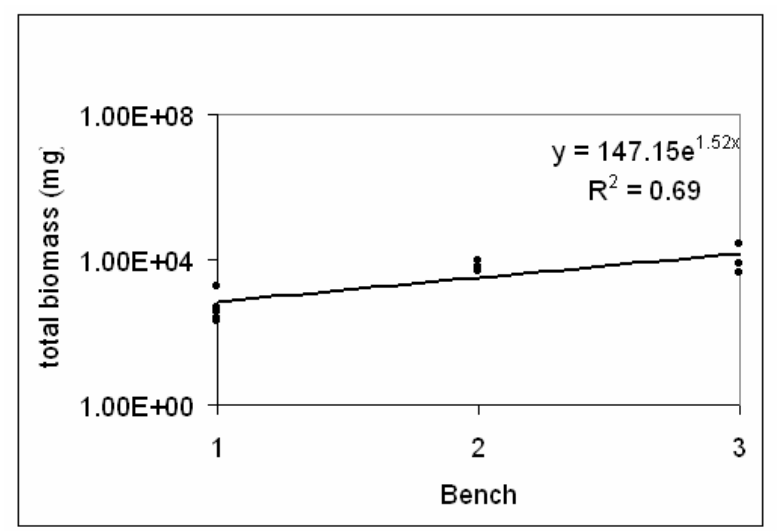

Fig. 1. Distribution of species abundance in size classes located on three benches

are presented in the table 1 . Characteristic values of bankfull calculated here using introduced IBA methods including the value of IBM indexes for each bench are given in the last column of the table 1 .

Table 1. Bankfull values for the Ochotnica Stream

\begin{tabular}{c|c|c|c|c|c|c|c}
\hline \multicolumn{6}{c}{ Bankfull discharge values in a cross-section within the investigated research reach, $Q_{b} \mathrm{~m}^{3} \cdot \mathrm{s}^{-1}$} \\
\hline Woloszyn & $\begin{array}{c}\text { Pickup } \\
\text { and } \\
\text { Warner }\end{array}$ & Wolman & Riley & $\begin{array}{c}\text { Schumm, } \\
\text { Brown and } \\
\text { Warner }\end{array}$ & Williams & Woodyer & $\begin{array}{c}\text { IBA method } \\
\text { (Invertebrate } \\
\text { Bankfull Assess- } \\
\text { ment method) }\end{array}$ \\
\hline first & $Q_{10 \%}$ & minimum & first & $n=0.02$ & Williams' & high & bench 3 \\
terrace & 38.40 & $W / D$ in- & index & minimum & equation & bench & $I \ll 4$ \\
13.88 & $Q_{25 \%}$ & dex & value & 23.37 & 19.94 & 40.47 & 38.40 \\
second & 21.20 & 4.10 & 8.88 & $n=0.025$ & & middle & bench 2 \\
terrace & central & & local & average & & bench & $I \leq 1$ \\
4.10 & value & & index & 18.67 & & 11.10 & $11.10 \div 38.40$ \\
& 29.80 & & value & $n=0.03$ & & low & central value 24.75 \\
& & & 4.10 & maximum & & bench & bench 1 \\
& & & 15.58 & & 3.20 & $I>1$ \\
& & & & & $4.10 \div 11.10$ \\
\end{tabular}

As long as the identified benches where particular IBA index was characteristic, these benches were compared with those levels of previously identified $t$-years flood levels. Next are calculated the discharges adequate for IBA benches. Out of calculated values from table 1 we considered bench 2 for proposed in the following paper IBA method with its central value out of other discharges where one could expect to find bankfull. So, calculated are the central values of discharge out of all 
ranges of bankfull discharges mentioned above which were referred to different abiotic and biotic methods and next is calculated an arithmetical average for them which is $Q=18.42 \mathrm{~m}^{3} \cdot \mathrm{s}^{-1}$. That value is termed here the bankfull value to which one could refer as to one number $Q_{b}=18.42 \mathrm{~m}^{3} \cdot \mathrm{s}^{-1}$. This number is a bigger then $Q_{50}=11.30 \mathrm{~m}^{3} \cdot \mathrm{s}^{-1}$ (the two years flood) but still close to $Q_{25}=21.2 \mathrm{~m}^{3} \cdot \mathrm{s}^{-1}$ what follows the general statements of bankfull definition given by many authors. Finally the obtained $Q_{b}=18.42 \mathrm{~m}^{3} \cdot \mathrm{s}^{-1}$ confirms the present hydrological situation in that part of the Polish Carpathians where big floods were experiences in 1997, 2000 and 2003. Trying to discuss why the water level has the influence on invertebrates living within river corridor cross section and at the same time invertebrates might be considered as indicators when talking about bankfull we noticed that Principal Component Analysis described 70\% of variance for the first two axes of species data. Ordination axes (Fig. 2) clearly indicate changes in community composition and relative abundance of species belonging to three $t$-years flood levels called here for simplicity of the discussion here benches similarly as in the WOODYER'S study (1968) but in the respect of possibility of installing the invertebrate pitfall traps within the measuring (research) area. The right-hand group of assemblages belong to the first bench - so called Bench 1 - associated with Q discharge value between $Q=4.10 \div 11.10 \mathrm{~m}^{3} \cdot \mathrm{s}^{-1}$ which is nearly the low bench discharge value in the Woodyer's method, the most frequently flooded, even isolated by main stream, meanwhile left bottom group is composed from assemblages belonging to the second bench.

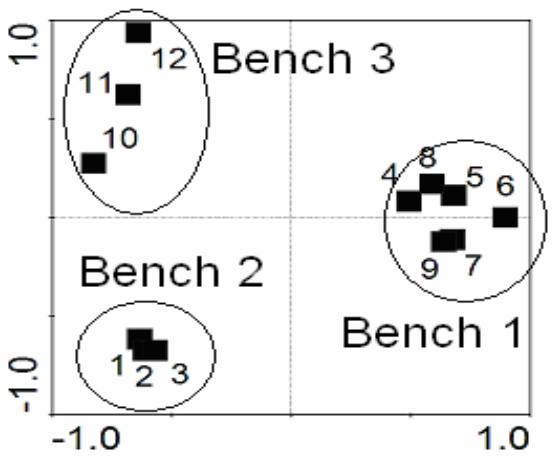

Fig. 2. Biplot based on principal component analysis of ground beetles assemblages (1-12)

Surprisingly, the top left group of assemblages, in spite of completely different environmental conditions (meadow-spruce forest) still have similar species composition and structure. The primary results of Canonical Correspondence analysis are presented in Figure 3. 


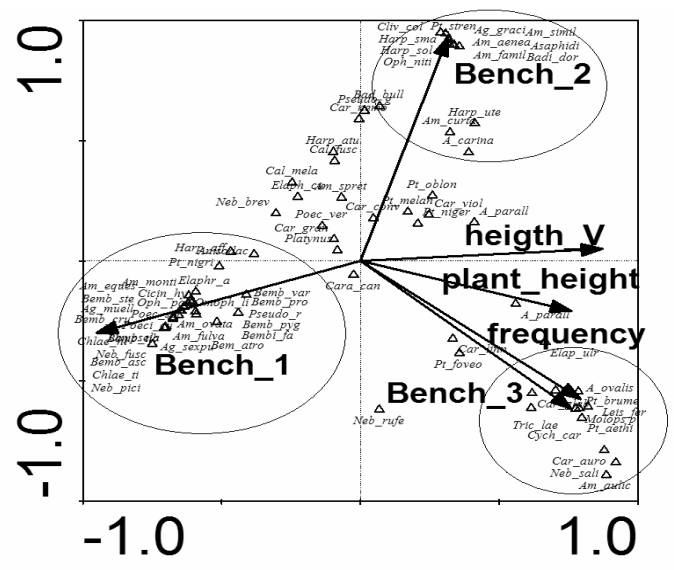

Fig. 3. Ordination diagram based on canonical correspondence analysis of ground beetle assemblages with respect to environmental variables (height_V distance from the deepest point in the stream, plant_height - average height of plants in given site, frequency - frequency of floods at each site and bench_1 - 3 location on particular bench as a dummy variables)

A Monte Carlo permutation test indicated significance of the first canonical axis $(F=2.4, p=0.02)$, as well as four axes $(F=1.51, p=0.05)$. Cumulative percentage variation of environmental-species data is about eighty percent for the first two axes. Variation in fluctuation of water level seems to be the main factor responsible for changes in species composition. Along Bench 1 concentrate small (4.5-7 mm) species, mostly belonging to genus Bembidion. Second bench so called Bench 2, associated with discharge range from $Q=11.10 \mathrm{~m}^{3} \cdot \mathrm{s}^{-1}$ to $Q=38.40 \mathrm{~m}^{3} \cdot \mathrm{s}^{-}$ ${ }^{1}$ (ordinate mostly distribution of medium sized species, characteristic for disturbed habitats (e.g. Pterostichus melanarius), meanwhile third bench described well distribution of mostly bigger forest species (eg. Carabus auronitens, Molops piceus).

\section{CONCLUSIONS}

1. Proposed and described along the paper Invertebrate Assessment Bankfull method (IBA method) could be adopted to find out the bankfull discharge value in gravel bed rivers. It can be used by anybody, even not experienced in the field of ecology or biology. This method is very straight forward when applying it in practice since it requires just an easy way of collection of the material (beetles) and there is no even a need to know species but just only one need to measure their sizes and then to calculate a simple IBA index.

2. It is possible to predict the value of the bench in the proposed IBA method according to equation $y=147.15 e^{1.5239 x}$, where $x$ is the known biomass of dominant 
species in given bench. One could do it just only by choosing the most abundant species from community (dominant one) present at the particular area.

3. Both a shape and size of insect bodies is highly connected with frequency of natural disturbances caused by occurrence of variety of discharges in a particular stream cross section. In that context if any of discharges can be considered as bankfull discharge dimensions of the beetles are strictly associated with that bankfull value.

4. The distribution of biomass in carabid beetles assemblages is correlated with places of occurrence of specific assemblages, therefore it depends on bankfull level or/and river bench also associated with a bankfull stage.

5. High flood frequency is a main factor causing changes in distribution of body size of beetles in relation to theoretical models and becomes more left skewed.

\section{LITERATURE}

1. Andersen J., 1969. Habitat choice and life history of Bembidion (Col., Carabidae) on river banks in central and northern Norway. Norsk Entomologisk Tidsskrift, 17: 17-65.

2. BRAY D.I., 1972. Generalised regime-type analysis of Alberta Rivers. PhD thesis. Edmonton, Canada, Univ. Alb.

3. DURY G.H., 1977. Underfit streams: retrospect, perspect and prospect. In: River channels. Ed. K.J. Gregory. Chichester, Willey: 281-293.

4. NIXON M.A., 1959. Study on the bank-full discharges of rivers in England and Wales. Proc. Inst. Civil Eng., 12: 157-174.

5. PICKUP G., WARNER R.F., 1976. Effects of hydrologic regime on magnitude and frequency of dominant discharge. J. Hydrol., 29: 51-75.

6. RADECKI-PAWLIK A., 2002. Bankfull discharge in mountain streams: theory and practice. Earth Surface Proc. Landforms, 27: 115-123.

7. RAdeCKi-PAWLiK A., SkAlSKi T., 2007. Estimation of bankful discharge - abiotic and biotic methods. College Cherlston, Dept. Geol. Env. Sci., Charleston, South Carolina, USA, P. Elek.: 26.

8. RAdecki-PAWLiK A., SKalSKi T., 2008. A new concept to determinate bankfull discharge using invertebrate communities - an example from the Ochotnica Stream, Polish Carpathians. EJPAU, 11, 1: $1-13$.

9. RAINIO J., NiEMELÄ J., 2003. Ground beetles (Coleoptera: Carabidae) as bioindicators. Biodivers. Conserv., 12: 487-506.

10. RILEY S.J., 1972. A comparison of morphometric measures of bankfull. J. Hydrol., 17: 23-31.

11. Schumm S.A., 1960. The shape of alluvial channels in relation to sediment type. U.S. Geol. Surv. Prof. Pap., 352: 30.

12. TER BRAAK C.J.F., 1986. Canonical correspondence analysis: A new eigenvector technique for multivariate direct gradient analysis. Ecol., 67: 1167-1179.

13. THIELE H.U., 1977. Carabid beetles in their environments. Berlin, Springer.

14. WERRITTY A., 1997. Short-term changes in channel stability. In: Applied fluvial geomorphology for river engineering and management. Eds CR Thorne, RD. Hey, MD. Newson. Chichester, John Wiley \& Sons: $47-65$.

15. WiLliams P.G., 1978. Bankfull discharge of rivers. Water Resour. Res., 14: 1141-1154. 
16. Wolman M.G., 1955. The natural channel of Brandywine Creek, Pensylvania. U.S. Geol. Surv. Prof. Pap. 282: 86-109.

17. Woloszyn J., Czamara W., Eliasiewicz R., Krężel J., 1994. Regulacja rzek i potoków (River training works). AR, Wrocław: 540.

18. Woodward G., Ebenman B., Emmerson M., Montoya J.M., Olesen J.M., Valido A., Warren P.H., 2005. Body size in ecological networks. Trends Ecol. Evol., 20: 402-409.

19. WOODYER K.D., 1968. Bankfull frequency in rivers. J. Hydrol., 6: 114-142.

\section{STRESZCZENIE}

\section{Wyznaczenie wartości przepływu brzegowego za pomocą nowej metody IBA: Invertebrate Bankfull Assesment Method}

Stowa kluczowe: biegaczowate, biomasa, Karpaty Polskie, potok górski, przeptyw brzegowy

W pracy przedstawiono nową metodę wyznaczenia wartości przepływu brzegowego na wybranym odcinku rzeki górskiej. Metodę nazwano IBA od angielskiej nazwy: Invertebrate Bankfull Assesment Method. Metoda ta umożliwia określenie wartości przepływu brzegowego w zależności od tego, na jakiej wysokości brzegu potoku górskiego żyją zwierzęta makrobezkręgowe (tu zastosowane jako wskaźnikowe: biegaczowate), tolerujące lub nietolerujące zalew wodą. Badania metodycznie przeprowadzono w zlewni potoku Ochotnica w Gorcach - w Karpatach Polskich. W artykule wyznaczono trzy poziomy, na których żyją określone biegaczowate.

Reviewers:

Prof. Andrzej Ciepielowski

Dr Tomasz Szymczak 